\title{
APRESENTAÇÃO
}

\section{RECEPÇÃO ANTIGA E MODERNA DA ILÍADA}

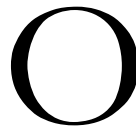

$\mathrm{s}$ artigos reunidos neste dossiê se originam, em sua maioria, do colóquio "A Ilíada de Homero e sua recepção na Antiguidade e Modernidade", que ocorreu na Universidade de São Paulo em setembro de 2018 e para o qual se solicitou aos convidados que buscassem investigar como e por que a tessitura poética, retórica, teológica e ideológica do poema se plasmou nos textos que o refletiram.

Esse evento foi organizado pelos seguintes membros do grupo de pesquisa "Gêneros poéticos na Grécia antiga: tradição e contexto" (USP/CNPq): Christian Werner, Breno Battistin Sebastiani e Fernando Rodrigues Jr. (USP); Antonio Orlando Dourado-Lopes e Teodoro Rennó Assunção (UFMG); e Lucia Sano (UNIFESP). Seu financiamento foi obtido junto à FAPESP (processo no. 2017/266502), ao Programa de Pós-Graduação em Literatura (área de Estudos Clássicos e Medievais) da Faculdade de Letras da Universidade Federal de Minas Gerais e ao Departamento de Literaturas Clássicas e Vernáculas da Faculdade de Filosofia, Letras e Ciências Humanas (USP).

A única exceção é o artigo de Peter Grossardt, apresentado, em uma versão preliminar, no "II Colóquio Internacional sobre Poesia Grega Arcaica do NEAM/ UFMG: Poesia Hexamétrica”, organizado por Antonio Orlando Dourado-Lopes e Teodoro Rennó Assunção, ocorrido em Belo Horizonte no mesmo mês de 2018.

Os textos aqui coligidos abarcam a recepção de aspectos da Ilíada na Antiguidade e Modernidade que não se resumem a seu esqueleto narrativo, aquele composto pelas consequências da ira de Aquiles, forma particular de uma história tradicional que, como mostra o texto de Peter Grossardt, está presente em diferentes tradições orais independentemente do poema de Homero.

O status canônico da Ilíada se manteve inabalável na Antiguidade clássica, como exemplificam os textos de Lucia Sano, Fernando Rodrigues Jr., Paulo Sérgio Vasconcellos, Adriane Duarte e Gustavo Araújo de Freitas. Já na Modernidade, como discutem Tereza 
Virgínia Barbosa, Graciela Zecchin de Fasano e Maria de Fátima Silva, o poema sempre de novo produziu diálogos críticos, inclusive e de diversas formas, por meio de suas traduções, como desenvolve, de forma bem-humorada mas também arguta, o poema-ensaio de Marcelo Tápia, uma contribuição que se afasta, de certa forma, do tipo de texto previsto pela linha editorial da revista Classica, mas como que compõe a cereja do bolo deste dossiê.

Espera-se, portanto, que esta coleção de textos não apenas reflita a posição que Homero e, em particular, a Ilíada, ocupam em um amplo espectro de discussões nos estudos clássicos, mas também dialogue de forma profícua com outros dois dossiês dessa revista, o "Homero" (Classica v. 29, n. 1) e o "Poesia hexamétrica grega", ainda por vir (Classica v. 32, n. 2).

Christian Werner Breno Battistin Sebastiani Lucia Sano, os organizadores. 